\title{
Some Thoughts on Monopoly, Markets, and Mergers
}

\author{
Michael Malina $\dagger$
}

In assessing the current state of our jurisprudence under section 2 of the Sherman $\mathrm{Act}^{1}$ and section 7 of the Clayton Act, ${ }^{2}$ the problem we confront today is one that has troubled courts, commentators, and counselors from antitrust's very beginning: How to fashion doctrines that not only make economic sense and provide businesses with sufficient flexibility to compete in the real world of the marketplace, but also are administrable as rules of law. Although we have made great strides over the past few decades in fine-tuning doctrine to take account of economic insights and to avoid much of the unduly restrictive rigor of past decisions, ${ }^{3}$ we have yet to translate these theoretical doctrines into workable rules that lawyers and judges can consistently apply.

To deal first with the monopohzation offense of section 2 of the Sherman Act, Professor Areeda correctly notes that it is the most elusive of all antitrust offenses, as well as the most dangerous, since it does not require concerted action. ${ }^{4}$ While the elements of the offense are now well settled-possession of monopoly power and either willful acquisition or willful maintenance of that power ${ }^{5}$-this fornulation is hardly a useful tool either for judicial decisionmaking or business counseling.

Just what does it mean to willfully acquire or maintain monopoly

$\dagger$ Partner, Kaye, Scholer, Fierman, Hays \& Handler, New York, N.Y. A.B. 1957, LL.B. 1960, Harvard University.

1. 15 U.S.C. $§ 2$ (1982) (original version at ch. $647, \S 2,26$ Stat. $209(1890)$ ).

2. 15 U.S.C. $\S 18$ (1982 \& Supp. III 1985) (original version at ch. $323, \S 7,38$ Stat. 730, 731 32 (1914)).

3. Compare, eg., United States v. General Dynamics Corp., 415 U.S. 486, 498 (1974) ("statistics concerning market share and concentration, while of great significance, [are] not conclusive indicators of [the] anticompetitive effects [of a merger]") with United States v. Von's Grocery Co., 384 U.S. 270, 278 (1966) (holding the defendant in violation of section 7 of the Clayton Act even though the "market was competitive before the merger, has been since, and may continue to be in the future").

Compare also Paschall v. Kansas City Star Co., 727 F.2d 692, 704 (8th Cir.) ("[T]here is nothing unlawful about the mere possession of monopoly power. Nor is it unlawful per se for a monopolist to unilaterally refuse to deal with a former distributor or to vertically integrate."), cert. denied, 105 S. Ct. 222 (1984), with Otter Tail Power Co. v. United States, 410 U.S. 366 (1973) (holding that defendant's refusal to sell electric power at wholesale to competing municipal systems violated section 2 of the Sherman Act).

4. Areeda, Monopolization, Mergers, and Markets: A Century Past and the Future, 75 CALIf. L. REv. 959, 960-61 (1987).

5. United States v. Grinnell Corp., 384 U.S. 563, 570-71 (1966). 
power? The decided cases tell us precious little. Indeed, the concept of monopoly power itself is difficult to pin down. The standard definition from Dupont ${ }^{6}$ - "the power to control prices or exclude competition"7 lacks the precision necessary to make the law readily applicable. This is especially problematic since, as Professor Areeda notes, the task of determining whether the standard has been satisfied often falls on a lay jury. ${ }^{8}$ It is therefore hard to disagree with Professor Areeda's call for better techniques for assessing power and, concomitantly, for defining markets.

The task of rendering section 2 pragmatically applicable is not, however, an easy one. The traditional approach-at least since Learned Hand's seminal discussion of the question in Alcoa $^{9}$ - has been to define the relevant market first and then to inquire whether the putative monopolist possesses power in that market. That methodology, however entrenched it may be, is circular, since the process of market definition itself entails an assessment of the markct participants' power to raise price without competitive constraints from other sellers.

Despite the problem of circularity, which may well be insoluble, antitrust in the 1980's has made significant progress in addressing the issue of market definition. The Department of Justice's Merger Guidelines, promulgated in 1968 and revised in 1982 and $1984,{ }^{10}$ constituted a significant achievement in this area. The Guidelines introduced a cogent theory for defining markets and, by eliminating the submarket concept derived from Brown Shoe ${ }^{11}$ and its progeny, ${ }^{12}$ appear to have cured the most serious illness in that area of the law. ${ }^{13}$

Even so, that progress is exemplified by a marked contrast between theory and practice. What proves to be an intellectually satisfying methodology does not, ipso facto, create a pragmatically useful rule of law. A theoretical framework for determining the product and geographical parameters of pricing power that proceeds from a hypothetical increase by a hypothetical cartel of a hypothetical five percent in the price of a product is hardly a realistic tool for practitioners and judges to use in advising clients and deciding cases. That is not to say that the Guide-

6. United States v. E.I. du Pont de Nemours \& Co., 351 U.S. 377 (1956).

7. Id. at 391.

8. Areeda, supra note 4 , at 960 .

9. United States v. Aluminum Co. of Am., 148 F.2d 416, 424 (2d Cir. 1945). See Malina, The Antitrust Jurisprudence of the Second Circuit, 37 REc. A. B. CITY NEW YoRK 436, 466-69 (1982).

10. U.S. Dep't of Justice, Merger Guidelines, 49 Fed. Reg. 26,823 (1984).

11. Brown Shoe Co. v. United States, 370 U.S. 294 (1962).

12. E.g., United States v. Continental Can Co., 378 U.S. 441 (1964).

13. By focusing the market definition process on the power of the competing market participants to raise their prices without competitive constraint, the Guidelines leave little room for any concept of submarkets within markets and the opportunities for gerrymandering that that concept engendered. See Robinson, Recent Antitrust Developments: 1982, 4 CARDozo L. Rev. 551, $555-60$ (1983). 
lines' approach is without practical utility. But when it comes to testing the theory in the crucible of litigation, markets will still have to be proved in the old-fashioned way-with evidence of product interchangeability, price cross-elasticities, and other common indicia of competition.

While Fred Rowe underscores, with his characteristic wit and clarity, the shortcomings of market analysis as it has been applied by the courts, ${ }^{14}$ he fails to provide what Gilbert denoted in The Mikado as a "Lord High Substitute." Until a better construct for examining competition is developed, the concept of "relevant market" is, for better or worse, destined to remain.

Once the relevant market is defined, the conduct element of the monopolization offense-which is probably more important and more difficult to define with clarity than the relevant market-comes into play. Unlike the possession of monopoly power, which is significant only to the extent that the law imposes on the monopolist obligations not imposed on less powerful rivals, the conduct element is decisive on the issue of liability. Thus, special care should be taken to define the conduct element in order that it can be readily applied by lawyers, judges, and juries.

It is not insignificant that Professor Areeda did not pause to mention the concept of willful acquisition of monopoly power. The omission is not surprising, since, given the current state of the law, this aspect of the monopolization offense is of slight concern. If a company acquires assets that tend to confer monopoly power upon it, section 7 of the Clayton Act will probably come into play to prohibit the transaction. Acquisitions of monopoly power by means other than asset or stock acquisition-if they are to be of antitrust concern at all-are likely to involve the kind of anticompetitive or predatory conduct that would constitute willful maintenance. In other words, the willful acquisition aspect of the monopolization offense is not likely to apply to much conduct not proscribed by other provisions of the law.

Willful maintenance-whatever that means-is another matter. Here one is usually evaluating the conduct of a company that has achieved a substantial degree of market power through lawful means. Early efforts to set limits on what such a company may do once it lias acquired appreciable power over price tended to treat the successful competitor harshly. Learned Hand's Alcoa opinion, despite acknowledging that a rule that espouses vigorous competition while punishing the winner of the competitive struggle is self-defeating, ${ }^{15}$ nonetheless proclaimed a rule that, on its face at least, would prohibit a lawful monopolist from

14. Rowe, Market as Mirage, 75 CAL1F. L. Rev. 991 (1987).

15. "The successful competitor, having been urged to compete, must not be turned upon when he wins." United States v. Aluminum Co. of Am., 148 F.2d 416, 430 (2d Cir. 1945). 
charging a supracompetitive monopoly price. ${ }^{16}$ That is about as close as one can get to proscribing the status of monopoly, not merely the act of monopolization.

Happily, the doctrinal advance forward from Alcoa has been remarkable. Decisions such as Berkey Photo ${ }^{17}$ and the $I B M$ cases $^{18}$ have made it clear that the possession of lawfully obtained monopoly power does not disable a company from competing vigorously to maintain its market position, even though such conduct might, literally speaking, constitute "maintenance" of the monopoly position. By the same token, Judge Kaufman's opinion in Berkey relegated much of Learned Hand's Alcoa analysis to the history books by estabhishing that a monopolist may lawfully charge a supracompetitive monopoly price if the monopoly was lawfully achieved. ${ }^{19}$

With those principles apparently firmly in place-although the Aspen opinion, ${ }^{20}$ as Professor Areeda so cogently notes, does leave one wondering a bit ${ }^{21}$ - the question is: What is left that a company with legitimately achieved monopoly power may not do? As I see it, what is left is (1) a concept of predatory pricing that, due in large part to Professors Areeda and Turner, ${ }^{22}$ has boiled down to an analysis of price-cost relationships on an analytically sound basis; ${ }^{23}$ and (2) the somewhat vague idea that monopoly power may not be exercised to gain an unfair

16. See id. at 428 .

17. Berkey Photo, Inc. v. Eastman Kodak Co., 603 F.2d 263 (2d Cir. 1979) (holding that introduction of new products into the market without prior disclosure to competitors was valid conduct), cert. denied, 444 U.S. 1093 (1980).

18. Telex Corp. v. International Business Machs. Corp., 510 F.2d 894, 926 (10th Cir.), cert. dismissed, 423 U.S. 802 (1975); Transamerica Computer Co. v. International Business Machs. Corp., 698 F.2d 1377, 1383-84 (9th Cir. 1983); California Computer Prods., Inc. v. International Business Machs. Corp., 613 F.2d 727, 739-43 (9th Cir. 1979) (all involving vigorous competition by a monopolist engaged in pricing that competitors alleged to be predatory).

19. "[U]nless the monopoly has bolstered its power by wrongful actions, it will not be required to pay damages merely because its prices may later be found excessive. Setting a high price may be a use of monopoly power, but it is not in itself anticompetitive." Berkey Photo, 603 F.2d at 294. See also Malina, supra note 9, at 475-76.

20. Aspen Skiing Co. v. Aspen Highlands Skiing Corp., 105 S. Ct. 2847 (1985).

21. Areeda, supra note 4, at 963-65.

22. Areeda \& Turner, Predatory Pricing and Related Practices Under Section 2 of the Sherman Act, 88 HARV. L. REV. 697 (1975).

23. While the courts are not unanimous with respect to precisely what measure of cost should be examined to determine whether a price is predatory, some form of below-cost prieing is generally required. See, e.g., Barry Wright Corp. v. ITT Grinnell Corp., 724 F.2d 227, 235-36 (1st Cir. 1983) (holding that a price above both average and marginal cost cannot be predatory); Arthur $\mathrm{S}$. Langenderfer, Inc. v. S.E. Johnson Co., 729 F.2d 1050, 1058 (6th Cir.) (holding that "Sherman Act liability cannot be premised on alleged predatory pricing without some evidence that a defendant has charged below its total cost for the product sold"), cert. denied, 105 S. Ct. 510 (1984). But sce Transamerica Computer Co. v. International Business Machs. Corp., 698 F.2d 1377, 1387 (9th Cir. 1983) (holding that pricing above average total cost but below the profit maximizing level may, nevertheless, be predatory). 
advantage over one's competitors. In one of its manifestations, this latter doctrine has been characterized as involving the denial to competitors of access to an "essential facility."24

Widespread judicial acceptance of the Areeda-Turner thesis, at least as a rule of presumption if not of substantive law, has focused the predatory pricing offense on the relationship of a monopolist's price to his cost. This methodology has the distinct advantage of providing courts with a benchmark against which challenged conduct may be measured. Thus, one cannot reasonably quarrel with Professor Areeda's conclusion that this development is salutary. ${ }^{25}$

But with this sound shift of focus from the seller's hard-to-prove intentions to his demonstrable costs, there is a serious risk that, in the guise of protecting competitors from predation, courts will deprive consumers of the lower prices that antitrust ultimately seeks to promote. For that reason, the Supreme Court recently reminded us in the Matsushita case ${ }^{26}$ that a price below incremental cost is predatory only if it is hikely to lead to supracompetitive price and excess profits once the monopolist has eliminated his competition. ${ }^{27}$ Without engaging in a full discussion of the contested issue of price-cost relationships, I suggest that we carefully examine our predatory pricing doctrines and require at least a showing that alleged predation is likely to succeed in eliminating competition and elevating price before we condemn a seller for charging his customers too little.

On the issue of the anticompetitive use of monopoly power, particularly the essential facilities doctrine, the critical question is whether the Aspen decision can be limited to its peculiar facts or, if a bad pun may be allowed, it is more than a winter sport. Professor Areeda eloquently outlined the mischief in Justice Stevens's opinion. ${ }^{28}$ I would add a few points. First, the case turned on the Court's conclusion that the defendant's refusal to continue the joint arrangement with its competitor cost the defendant money in the short run, rendering the case analogous to a predatory pricing scenario. ${ }^{29}$ If proof of that circumstance was critical to the Court's rationale, perhaps the decision will not turn out to be doctrinally significant. Second, the jury instruction that Professor Areeda criticizes was not objected to at trial. ${ }^{30}$ Accordingly, the Court's entire

24. E.g., MCI Comm. Corp. v. American Tel. \& Tel. Co., 708 F.2d 1081, 1132 (7th Cir.), cert. denied, 464 U.S. 891 (1983).

25. Areeda, supra note 4, at 970 .

26. Matsushita Elec. Indus. Co. v. Zenith Radio Corp., 106 S. Ct. 1348 (1986).

27. Id. at 1358-59.

28. Areeda, supra note 4, at 963-65; see also Malina, Supreme Court Update-1985, 54 ANTITRUST L.J. 289, 291-95 (1985).

29. Aspen Skiing Co., 105 S. Ct. at 2860.

30. Id. at $2856 \mathrm{n} .26$. 
discussion of the issue may be, technically speaking at least, only dictum. In the final analysis, what is needed is a readily comprehensible rule of law that can be given to juries with the reasonable expectation that it will be understood and applied. Unfortunately, as almost a century of experience under section 2 teaches us, this salutary goal is still far from accomplishment.

Turning now to the future of merger jurisprudence under section 7 of the Clayton Act, discussion must begin with the Justice Department's Merger Guidelines. ${ }^{31}$ Once a market is delineated, the issue becomes one of determining the likely effect of a particular acquisition or merger on competition in that market. The Guidelines, like their predecessors and like the judicial authorities, look to market share concentration as a surrogate for competitive vigor. In that regard, the new prominence of the Herfindahl-Hirschman Index ${ }^{32}$ as a measure of concentration may provide us with a better yardstick.

However, the mathematical formulas in the Guidelines still do not provide a satisfactory answer to the ultimate question: How much concentration is too much? The current administration's virtually exclusive focus on horizontal acquisitions, and on the likely price effects of those transactions, leaves one with the feeling that the Guidelines' approach to nonhorizontal mergers needs to be reconsidered in order to come closer to the legislature's command. After all, legislative history clearly demonstrates that the 1950 Congress that passed the Celler-Kefauver Act intended to reach anticompetitive vertical and conglomerate mergers as well as horizontal ones. ${ }^{33}$ While the broad language of section 7 leaves room for enormous judicial flexibility, that section nonetheless reflects a legislative determination both that there are anticompetitive acquisitions that should not be permitted and that the prohibited category is not limited to mergers of competitors with large market shares.

Nevertheless, the Guidelines' mathematical formulas do serve one important function. They enable practicing lawyers and their clients to assess, however roughly, a transaction's section 7 exposure-at least from the point of view of the enforcement agencies-before the fact. That is of great practical value and should not be lightly dismissed.

In short, antitrust doctrines have significantly moderated extreme positions taken in the past but have yet to provide us with pragmatic and

31. For a discussion of the Guidelines' pervasive influence on the process of market definition, see supra text accompanying notes 10-14.

32. The Herfindahl-Hirschman Index (HHI) is used and explained in the U.S. Department of Justice's Merger Guidelines, 49 Fed. Reg. 26,823, 26,830-31 (1984).

33. See Handler \& Robinson, A Decade of Administration of the Celler-Kefauver Antimerger Act, 61 Colum. L. Rev. 629, 652-74 (1961). 
readily applicable tools for the future. That is the challenge of the next hundred years. 
